\title{
GEOLOGICAL CLASSIFICATION AND MAPPING OF TECHNOGENIC (ARTIFICIAL) GROUND: A COMPARATIVE ANALYSIS
}

Alex Ubiratan Goossens PELOGGIA

\begin{abstract}
Artificial or technogenic grounds have been described in geological literature since the $19^{\text {th }}$ century. However, their intense study, classification and systematic mapping have been carried out only since the 1980s, the principal contributions having originated in the former Soviet Union and Eastern Europe, the United Kingdom, the United States of America, Japan and Brazil, among others. Here we present a comparative analysis of some these main contributions, based upon their application to a hypothetical area, in order to verify their potential use and the adequacy of their methods. It is concluded that the combined use of characteristics of these approaches may be the most adequate depending on the purpose of the study and the scale adopted for mapping.
\end{abstract}

Keywords: Artificial or technogenic ground; Classification; Geological mapping.

\section{RESUMO}

\section{CLASSIFICAÇÃO E MAPEAMENTO GEOLÓGICO DE TERRENOS} TECNOGÊNICOS (ARTIFICIAIS): UMA ANÁLISE COMPARATIVA. Terrenos artificiais ou tecnogênicos são descritos na literatura geológica desde o século XIX. Todavia, seu estudo, classificação e mapeamento sistemático vêm sendo realizados muito mais intensamente a partir dos anos 1980, com contribuições provenientes de geocientistas da antiga União Soviética e do Leste Europeu, do Reino Unido, dos Estados Unidos da América, do Japão e do Brasil, dentre outras. Neste trabalho estudamos algumas dessas principais contribuições, por meio de uma análise comparativa a partir de sua aplicação a uma área hipotética, feita de modo a verificar suas potencialidades de uso e a adequação dos métodos. Conclui-se que o uso combinado de características dessas abordagens pode ser o mais adequado em função do objetivo do estudo e da escala de mapeamento adotada.

Palavras-Chave: Terrenos artificiais ou tecnogênicos; Classificação; Mapeamento geológico.

\section{INTRODUCTION}

The concept of artificial ground - also referred to as technogenic, anthropogenic or "man"made, or even humanly or artificially modified ground - was consolidated with the publication of the entry "Artificial Ground" in the Springer Publishing's Encyclopaedia of Engineering Geology (WATERS 2018), as well as the entry "Humanly Modified Ground" (EDGEWORTH 2017) in the Encyclopaedia of The Anthropocene, by Elsevier. While Waters defines artificial ground as areas in which anthropogenic activities directly modified the landscape by deposition and excavation, Edgeworth deals with the concept of the archaeosphere, in the sense of the totality of humanly modified ground is considered as a global entity, defining the humanly modified ground as consisting of settlement debris, dumped waste, landfill, reclaimed land, cut features, earthworks, cultivation soils and other kinds of ground significantly modified by humans.

In terms of classification, Waters' entry cites the generic use of the term "fill" in the context of 
Engineering Geology, noting that several schemes were developed to classify these grounds into units of distinct characteristics. Among these proposals are highlighted: 1) the geostratigraphic units proposed in Japan by NIREI et al. (2012), which differentiate time-layers related to deposition episodes, and material layers, and their associations, considered suitable for use in detailed investigations of specific sites; 2) the system of classification of anthrostratigraphic and technostratigraphic units proposed in the USA by HOWARD (2014); 3) the classification of technogenic ground presented in Brazil by PELOGGIA et al. (2014a), and; 4) the artificial ground classification developed in the UK by the British Geological Survey (BGS) for use in geological maps and terrain models of artificially modified ground, strongly based on morphogenetic attributes (MCMILLAN \& POWELL 1999, and later works). This latter model is treated in detail by WATERS (2018) in what concerns to classification procedures.

Proposals " 3 " and "4" have had repercussions on the mapping of anthropogenic ground in Brazil. However, as the afore mentioned classification scheme of PELOGGIA et al. (2014a) had important precedents, such as OLIVEIRA (1990) pioneering classification of technogenic deposits and its derivations proposed by PELOGGIA (1999) and MIRANDOLA \& MACEDO (2014), as well as the classification of geotechnical units based on ground profiles by BARROS \& PELOGGIA (1993), these proposals will be discussed initially.

Finally, we will discuss the classification of technogenic ground proposed by PELOGGIA (2017), which resulted from the improvement in the classification of the technogenic ground by PELOGGIA et al. (2014a), quoted by WATERS (2018). The proposals of NIREI et al. (2012) and HOWARD (2014) will not be treated because they have a striking stratigraphic character, which is beyond the scope of the present work, that is the classification of artificial ground for mapping, and will be discussed in later studies.

In this way, the studied proposals are geological (particularly engineering geological) as well as geomorphological, since they are usually applied through morphostratigraphic criteria, that is by means of the analysis of the related landforms and depositional surfaces, as for quaternary surficial deposits (MEIS \& MOURA 1984, MOURA 1994, HUGHES 2010). In addition, we will not address here, by a theoretical incompatibility, approaches that work involving the concepts of anthropogenic or urban "soils", where the term "soil" is used generally in the sense of ground, including also deposits. We consider the appropriateness of the expression to be reserved for soils properly, that is, pedogenetic, that underwent chemical or physical transformations by virtue of human actions.

It should be highlighted that, despite the existence of important studies from knowledge fields such as geoarchaeology and soil science using differentiated terminologies (see PELOGGIA 2015a, 2017, for a detailed discussion and revision of the literature for both cases), that will not be discussed in this paper by limitation of the subject. However, we will deal with three proposals referring to pioneering work in these areas (FANNING \& FANNING 1989, CURCIO et al. 2004, BORJA BARRERA 1993), in order to allow a comparison with the analised geological classifications.

Finally, it is explained that the term "ground" in the English language, meaning "the earth and stones from which the Earth is made" (PROCTER 1995), and especially the expression "made ground", is usual and unambiguous in the field of Geology, appearing since the nineteenth century and early twentieth century, as will be show in this paper, being nowadays commonly used by the British Geological Survey. In the modern sense, as viewed in the definitions from EDGEWORTH (2017) and WATERS (2018), it encompasses both technogenic deposits and landforms, as well as technogenic soils in a strict sense (that is, pedogenic soils modified by human action). That is, technogenic geodiversity and technogenic landforms (PELOGGIA et al. 2014a, b).

\section{DISCUSSION OF THE GEOLOGICAL CLASSIFICATION OF ARTIFICIAL GROUND}

In order to discuss comparatively the afore mentioned classifications referring to artificial or technogenic ground and, at the same time, the potentialities of its cartographic representation, we will use a hypothetical example, consisting of an area without definite scale and with a geological substrate conventionally mapped (that is, representing lithological types, without the indication of surface formations and with the exception of alluvial deposits). In this area there are geological and geomorphological elements due to or derived from human activities, such as diverse landfills, siltation deposits, cutting slopes and erosion ravines induced by the use of 
the territory (Figure 1). Different from WATERS (2018) conception, which restricts the artificial ground to those formed directly by human agency, we will adopt here the approach that has been widely used in Brazil since the pioneering work of OLIVEIRA (1990), which includes induced sedimentary deposits or anthropogenic alluvium (see OLIVEIRA et al. 2005, PELOGGIA et al. 2014b, PELOGGIA 2017 and FRANÇA et al. 2018, for a review on Brazilian works concerning technogenic ground).

In fact, HOWARD (2017) observes that the identification of anthropogenic deposits of an indirect character, that is, resulted from unintentional human actions, as proposed by PELOGGIA et al. (2014b), is sometimes difficult in the field (and even the presence of artefacts by themselves may not be decisive). In fact, it is extremely possible that some anthropogenic sedimentary formations have not been characterized as such at first, because they have not been distinguished from natural sediments. However, in the field our observations have shown the possibility of using certain criteria as good indicators of anthropogenic alluvium (PELOGGIA 2015b, 2016; PELOGGIA et al. 2015). These criteria are related to the presence of anomalous geomorphological and sedimentologic characteristics of the deposits, in relation to that expected from the quaternary ecological, climatic and tectonic settings, such as sedimentation patterns, textural and mineralogical (im)maturity of sediments (suggesting accelerated erosion processes) and presence of "inexplicable" relief forms in the context. In the laboratory, the identification of technogenic clasts - microartefacts, or micro-technofossils, just as suggested by ZALASIEWICZ et al. $(2014,2016)-$, such as "bottle glass" derived sand grains or plastic fibres, has been important. Moreover, in many cases other data sources, mainly historical or iconographical and literary descriptions may provide important clues to the characterization of the anthropogenic nature of the deposits.

May as it be, the research on anthropogenic alluvium (also named legacy sediments, postsettlement alluvium, induced anthropic formations, technogenic-sedimentary deposits or technogenic wash) has developed significantly in several parts of the world (e.g. BORJA BARRERA 1993, TRIMBLE 2008, BROWN et al. 2013, JAMES 2013, MACKLIN et al. 2014, RICHARDSON et al. 2014, DONOVAN et al. 2015, JORDAN et al. 2016, ROYALL \& KENNEDY 2016, LU et al. 2017, GRIMLEY et al. 2017, JAMES 2017), fully justifying the inclusion of these anthropogenic sedimentary deposits in the classification scheme.

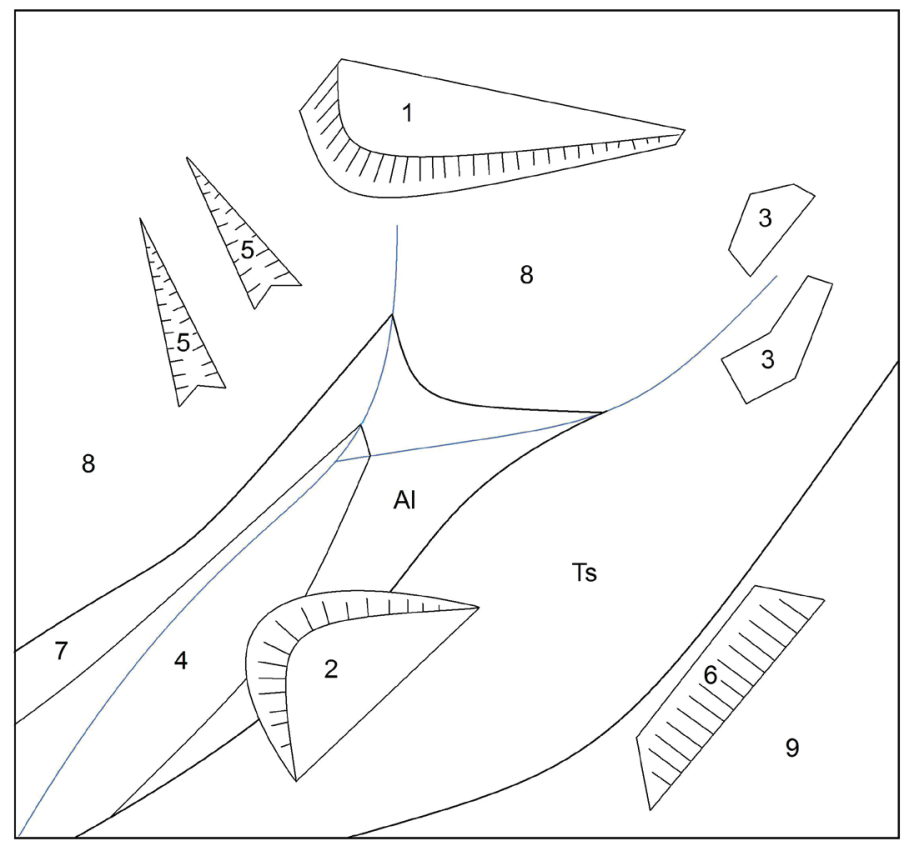

CONVENTIONAL

GEOLOGICAL MAP

(SCHEMATIC) WITH

ARTIFICIAL LANDFILLS

AND LANDFORMS

LANDFILLS

\begin{tabular}{|c|c|}
\hline 1 & Urban waste landfill \\
\hline 2 & Earthy material landfill \\
\hline 3 & Garbage deposit \\
\hline 4 & Silting deposit \\
\hline \multicolumn{2}{|c|}{ LANDFORMS } \\
\hline \multicolumn{2}{|c|}{5 याग Ravine } \\
\hline \multicolumn{2}{|c|}{6 IIITाT Cut slope } \\
\hline & Stream \\
\hline GEC & LOGICAL SUBSTRATUN \\
\hline 7 & Quaternary Alluvium \\
\hline 8 & Tertiary sediments \\
\hline 9 & Granite \\
\hline
\end{tabular}

FIGURE 1 - Map showing a hypothetical geological situation, without scale, with the occurrence of different types of deposits and technogenic features. 


\section{CLASSIFICATION OF TECHNOGENIC DEPOSITS BY OLIVEIRA (1990), ENHANCED BY PELOGGIA (1999)}

Based on the concept of technogenic deposit proposed by CHEMEKOV (1983), OLIVEIRA (1990) innovated by suggesting a general classification of these grounds into three basic types: constructed, induced and modified. Its application in the hypothetical situation studied is indicated in figure 2.

The concept is practical, allowing for the distinction of basic types of artificial ground, and is suitable for cartography on relatively small scales, even regional scales, including the possibility of overlapping pre-existing geological or pedological maps. However, it does not allow the distinction of different types within the main categories. This led to PELOGGIA's (1999) "Integrated Classification" proposal which, using the three previous categories, also uses the concept of "reworked deposit" (NOLASCO 1998), and includes the "remobilised" type, based on the concept of "remobilised cover", a specific category of technogenic deposit of urban hillslopes (PELOGGIA 1994). Thus, in addition to the genetic classification of OLIVEIRA (1990), PELOGGIA (1999) suggests the adoption of an operational procedure of characterization, which consists of the sequential incorporation of the parameters composition, structure, form of occurrence and technogenic environment. With regard to the item "composition", the above proposal incorporates concepts from FANNING \& FANNING (1989) on "highly man-influenced soils" (which actually concerns deposits), which distinguishes urbic (artefact rich), garbic (organic waste rich), spolic (earthy) and dredged (from waterways) materials, and also cutting features (scalped land surfaces). Figure 3 shows the application of PELOGGIA (1999) classification to the proposed geological situation.

The basic difference is, therefore, the differentiation of the technogenic deposits into types. However, these two proposals only deal with deposits, that is, they represent accumulated materials (aggradation ground, as proposed by PELOGGIA et al. 2014a, b), disregarding the anthropogenic features resulting from the removal of geological material (features of degradation). On another hand, the consideration of such features was proposed by MIRANDOLA \& MACEDO (2014), in a classification specifically focused on the mapping of risk areas, which we apply in figure 4.

Despite the terminology proposed by PELOGGIA (1999), that is, of urbic, garbic and spolic deposits, to be basically the same as that used in terms of the common language

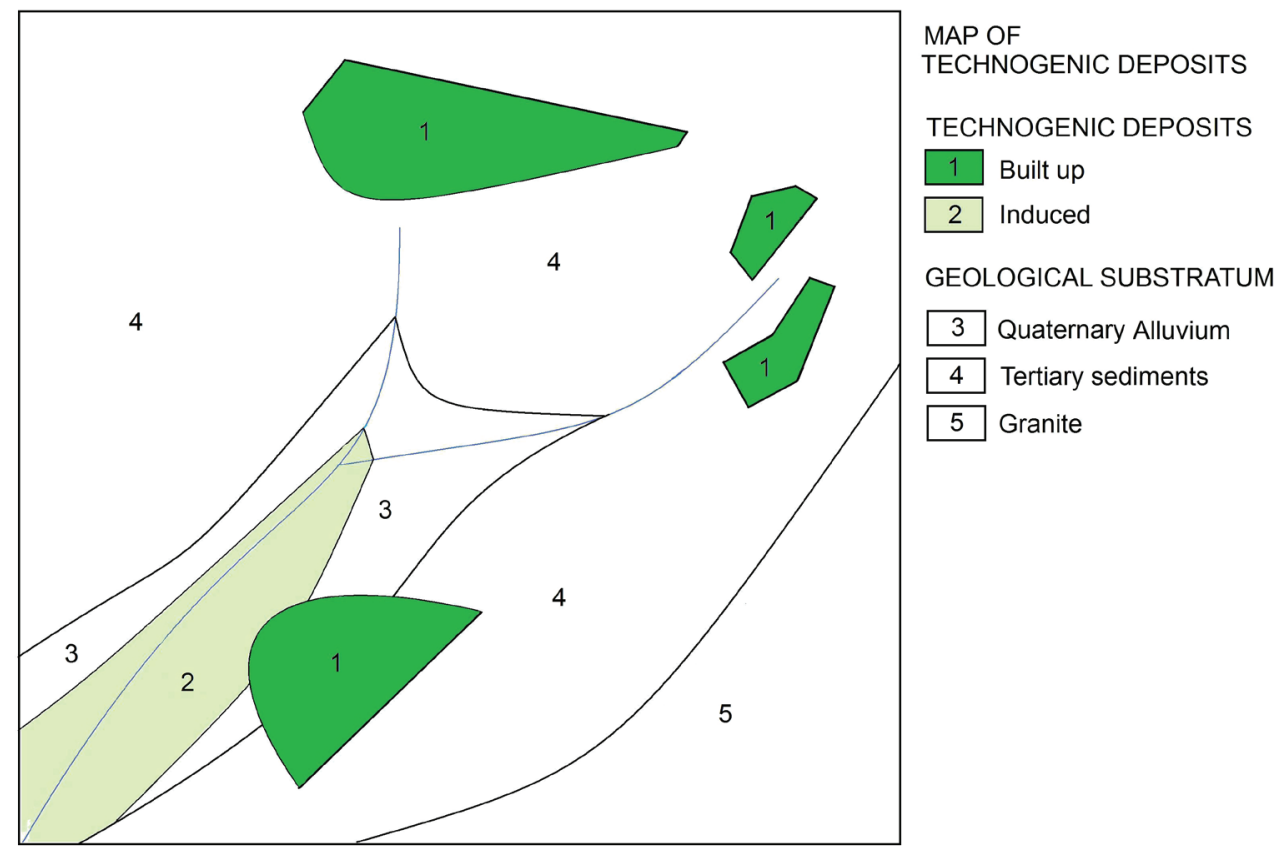

FIGURE 2 - Application of OLIVEIRA (1990) classification of technogenic deposits to the hypothetical geological situation shown in figure 1 . 


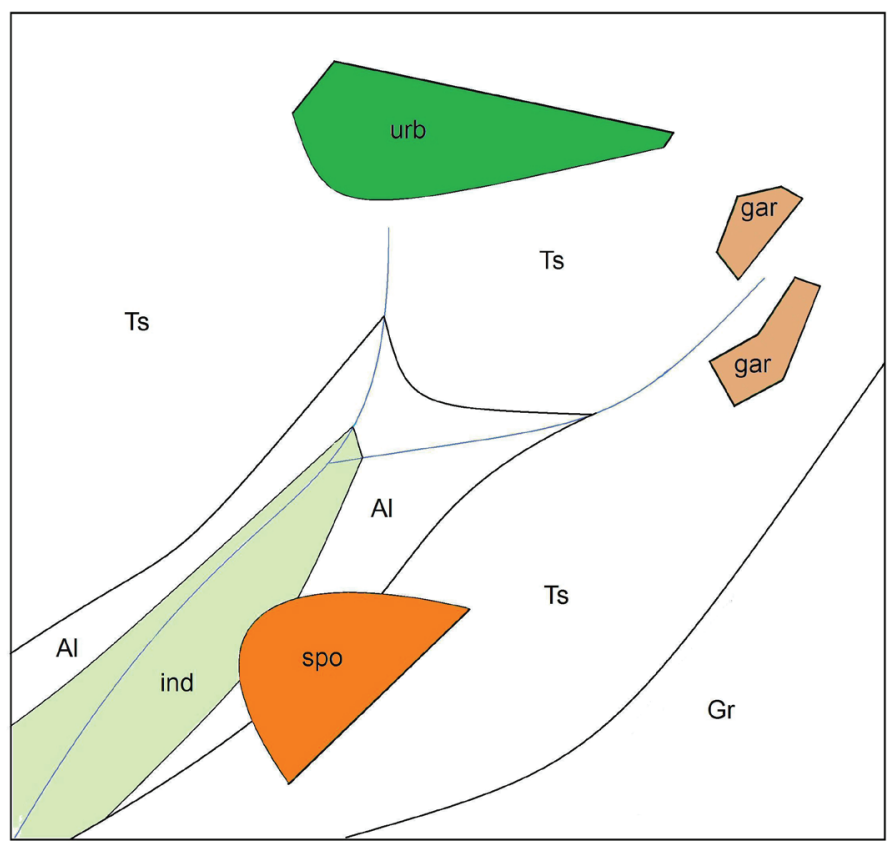

MAP OF TECHNOGENIC DEPOSITS

DEPOSITS

urb Urbic built up deposit

gar Garbic built up deposit

spo Spolic built up deposit

ind Induced sedimentary

GEOLOGICAL SUBSTRATUM

$\mathrm{Al}$ Quaternary Alluvium

Ts Tertiary sediments

$\mathrm{Gr}$ Granite

FIGURE 3-Application of the "Integrated classification" of technogenic deposits to the hypothetical geological situation shown in figure 1 .

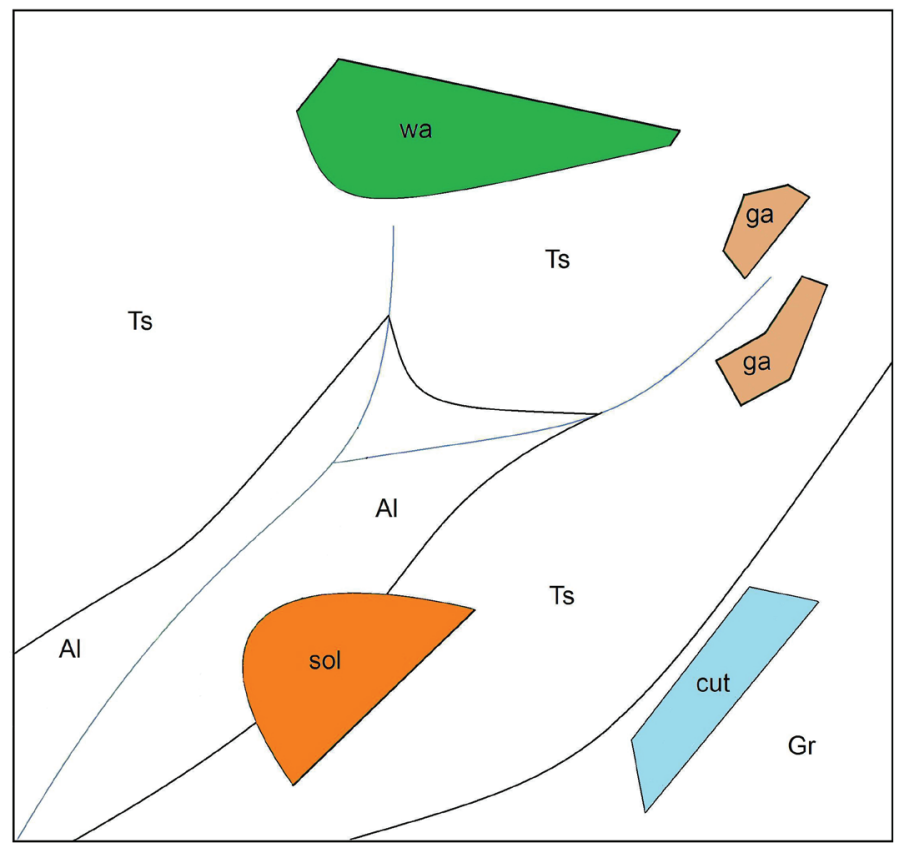

MAP OF TECHNOGENE FOR HAZARD ANALYSIS

TECHNOGENIC DEPOSITS

wa waste

ga garbage

sol soil

TECHNOGENIC FEATURES

cut cut

GEOLOGICAL SUBSTRATUM

Al Quaternary Alluvium

Ts Tertiary sediments

$\mathrm{Gr}$ Granite

FIGURE 4 - Application of the "Technogene classification for hazard areas" from MIRANDOLA \& MACEDO (2014) to the hypothetical geological situation shown in figure 1.

by MIRANDOLA \& MACEDO (2014), the maps have two fundamental differences: while in the first are represented the deposits of induced character (also known as anthropogenic alluvium, among other denominations, as we have seen), in the latter these are not considered, but appear as features of excavation (cuts), which also is present in the classification of artificial ground of the British Geological Survey, as we shall see. 


\section{THE CLASSIFICATION OF GEOTECHNICAL UNITS BASED ON GROUND PROFILES (BARROS \& PELOGGIA 1993)}

This is the first proposal of geotechnical cartography that used the concept of "remobilized covers", as cited as specific type of urban technogenic layer (described by PELOGGIA 1994), besides other "anthropic" deposits. The method was developed prior to MIRANDOLA \& MACEDO's (2014) proposal, essentially for detailed-scale mapping (1:500, as also mapped by BRAGA et al. 2016), and sought to solve the problem of the representation of layers and anthropogenic deposits laid upon differentiated natural terrains. It was due to the need to characterize them in terms of geotechnical behavior related mainly to susceptibility to erosion and landslides, or even subsidence, in a context of risk analysis or detailed intervention projects. However, the concepts related to technogenic deposits have not yet been fully utilized, but the common geotechnical nomenclature. The application of this scheme to the situation proposed in figure 1 is shown in figure 5 .

\section{THE CLASSIFICATION OF ARTIFICIAL GROUND OF THE BRITISH GEOLOGICAL SURVEY (BGS)}

Developed in the 1990s for local and regional geological mapping and conducted systematically on the territory of the United Kingdom (MCMILLAN \& POWELL 1999, ROSENBAUM et al. 2003, PRICE et al. 2004, FORD et al. 2010, PRICE et al. 2011), this classification consists of five basic classes, used for example in 1: 50,000 maps: the main one is the "made ground", as previously mentioned a term that has already appeared in British geological literature since the 19th century, with LYELL (2004[1863]), and the beginning of the Twentieth, with SHERLOCK (1922), which describes the formation of these grounds in London, and is equivalent to the concept of "schuttdecke" (debris cover), used by SUESS (1862) in the mapping of the Vienna substratum. This is followed by the classes of "infilled ground", "worked ground", "disturbed ground" and "landscaped ground".

In terms of cartographic representation, the particularity of this proposal consists of the use of hachure patterns, that can thus be superposed onto the conventional

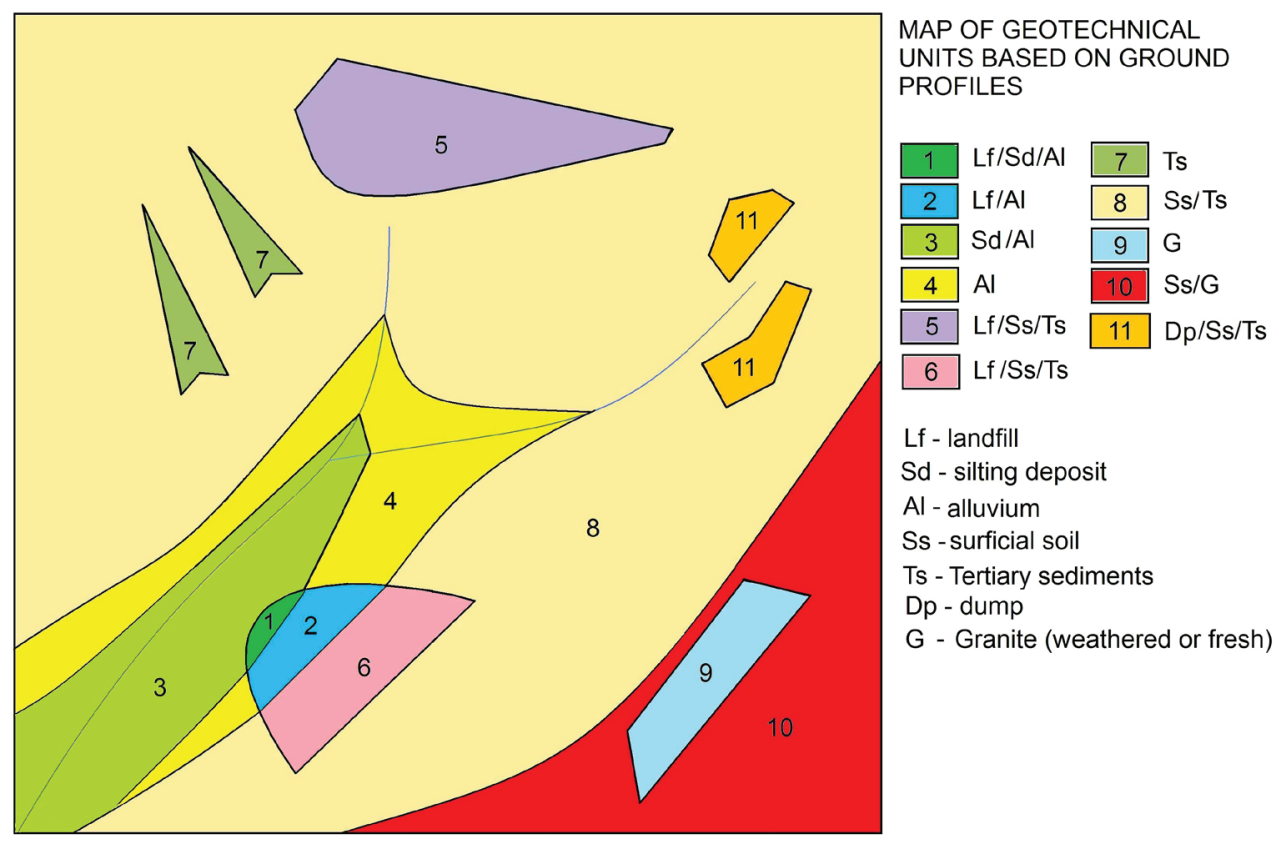

FIGURE 5 - Application of the geotechnical units proposed by BARROS \& PELOGGIA (1993) to the hypothetical geological situation shown in figure 1 . 
geological maps (that represent what the British call "solid and drift geology", that is to say, rocky substratum and superficial sedimentary formations) (Figure 6). So, the map that was presented here uses the coloured representation of the substrate. The cited method also has a distinct morphostratigraphic connotation (FORD et al. 2014), since it relies heavily on the identification of landforms, which also allows for the differentiation of the previous mentioned classes in types and units (both of which are not represented here), identified by codes of three or four letters, respectively, which are appropriate categories for more detailed mappings (scales of 1: 10,000 or greater).

In Brazil, the cartographic pattern proposed by the BGS was used and adapted, for example, by SANTOS et al. (2017) for mapping of technogenic ground in Guarulhos municipality, State of São Paulo.

\section{THE CLASSIFICATION OF}

TECHNOGENIC GROUND BY PELOGGIA et al. (2014a, b) AND FURTHER REFINEMENTS

It should be emphasized that, in fact, the scheme quoted from PELOGGIA et al. (2014a), referred to by WATERS (2018), and also referred to as the "technogenic geodiversity" classification, represents a conjugation of the BGS classification model described above with the classification schemes of the 1990s (OLIVEIRA 1990; PELOGGIA 1994, 1997, 1998, 1999), which had basic reference concepts from Soviet engineering geology (CHEMEKOV 1983, TER STEPANIAN 1988) and North American soil science (FANNING \& FANNING 1989). So, this proposal encompasses the main aspects necessary for the differentiation and mapping of artificial ground, since it adds to the British classification the concepts of induced deposits (formed indirectly as a consequence of human activity) and of technogenic soils (differentiating them from deposits).

The proposal, presented here in the form enhanced by PELOGGIA (2017), considers four basic ground classes (aggraded, degraded, modified and complex), associating to each one geological categories (respectively technogenic deposits, technogenic soils, exposed or moved substratum and technogenic landscapes). Each category, in turn, can be divided into types, each corresponding to specific technogenic layers or landforms (Table 1), for which it is applicable a scheme of facies classification (Table 2).

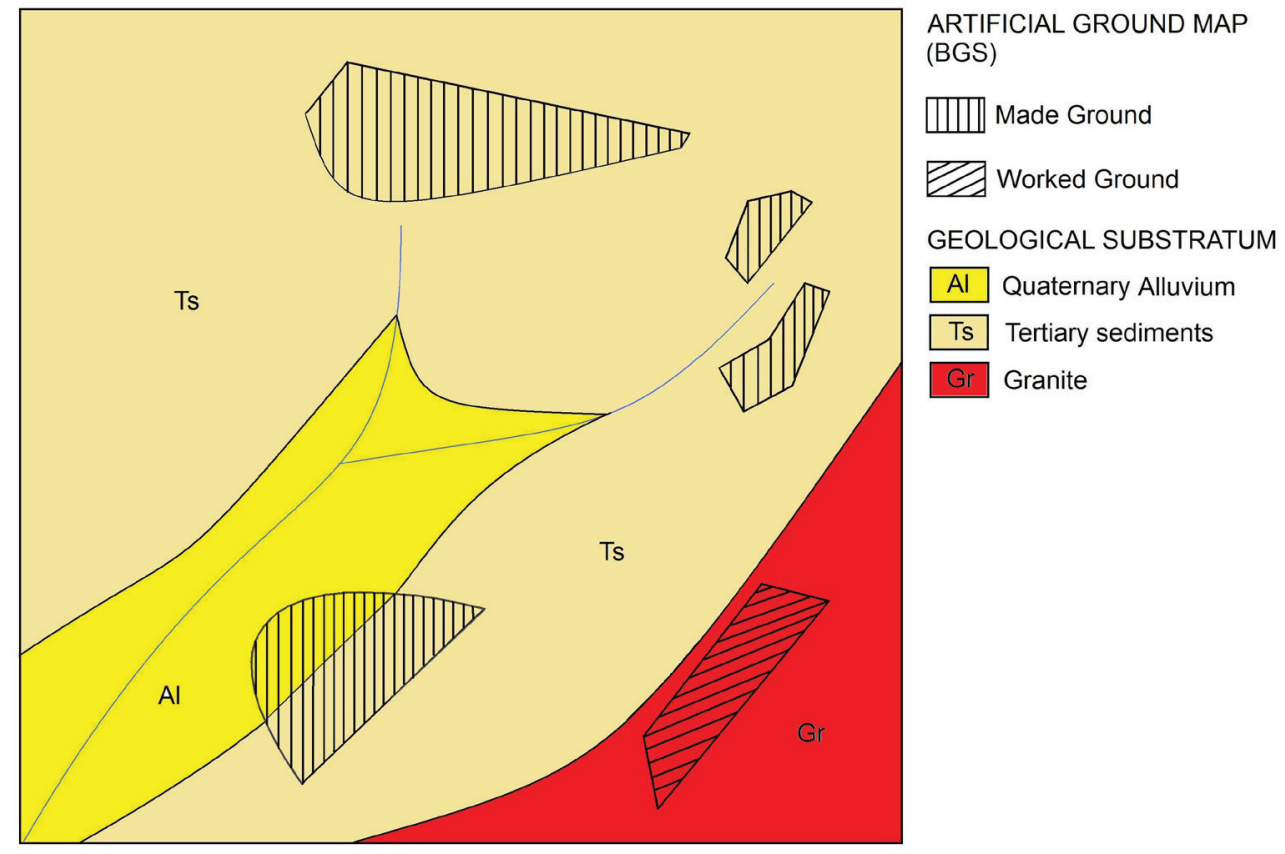

FIGURE 6 - Application of the British Geological Survey classification of artificial ground to the considered hypothetical area to the hypothetical geological situation shown in figure 1. 
TABLE 1 - Classification of technogenic (artificial) ground (PELOGGIA 2017).

\begin{tabular}{|c|c|c|c|c|}
\hline $\begin{array}{l}\text { Ground } \\
\text { Class }\end{array}$ & $\begin{array}{l}\text { Geological } \\
\text { category }\end{array}$ & Gro & und type & Technogenic layer or feature/landform \\
\hline \multirow{8}{*}{ 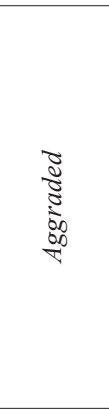 } & \multirow{8}{*}{ 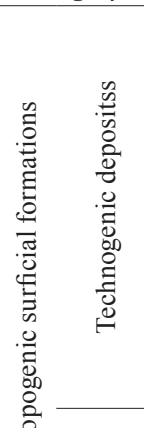 } & \multirow[b]{2}{*}{ Made Ground (*) } & Landfilled ground & Technogenic built up deposits (landfills) \\
\hline & & & $\begin{array}{l}\text { Occupational ground } \\
(* *)\end{array}$ & Cultural or occupational layers \\
\hline & & \multicolumn{2}{|c|}{ Infilled Ground $(*)$} & Made ground covering worked ground \\
\hline & & \multirow{2}{*}{$\begin{array}{l}\text { Technogenic } \\
\text { Sedimentary } \\
\text { Ground }\end{array}$} & Alluvial & $\begin{array}{l}\text { Technogenic alluvium-like deposits (anthropogenic } \\
\text { alluvium, legacy sediments, post settlement alluvium, } \\
\text { technogenic wash) }\end{array}$ \\
\hline & & & Colluvial & Technogenic colluvium-like deposits \\
\hline & & \multicolumn{2}{|c|}{ Landslided ground } & Induced mass movement deposits \\
\hline & & \multicolumn{2}{|l|}{ Displaced ground } & Remobilised technogenic deposits \\
\hline & & \multicolumn{2}{|l|}{ Mixed ground } & Superposition of different kinds of technogenic layers \\
\hline \multirow{2}{*}{ 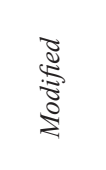 } & \multirow{2}{*}{ 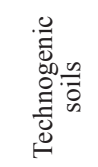 } & \multicolumn{2}{|c|}{ Chemically modified ground } & Contaminated soil horizons \\
\hline & & \multicolumn{2}{|c|}{ Mechanically modified ground } & Compacted or revolved soil horizons \\
\hline \multirow{4}{*}{ 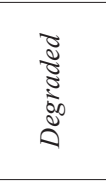 } & \multirow{4}{*}{ 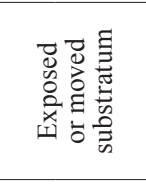 } & \multicolumn{2}{|l|}{ Eroded ground } & Erosion scars due to induced processes \\
\hline & & \multicolumn{2}{|c|}{ Scared ground } & Slip surfaces created by induced processes \\
\hline & & \multicolumn{2}{|c|}{ Sunken or Disturbed ground $(*)$} & Induced subsidence sinkholes \\
\hline & & \multicolumn{2}{|c|}{ Excavated or Worked ground $(*)$} & Excavation surfaces \\
\hline$\frac{3}{3}$ & 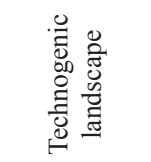 & \multicolumn{2}{|c|}{ Landscaped ground $(*)$} & $\begin{array}{l}\text { Ground formed by the complex aggregation or overlap } \\
\text { of technogenic deposits or soils, or exposed substratum } \\
\text { surfaces, not differentiable in the adopted mapping scale }\end{array}$ \\
\hline
\end{tabular}

The occurrence of later processes that affect the configuration or composition of the technogenic ground (such as erosion, mass movement, presence of groundwater or soil formation by pedogenesis) should be added to the ground type with appropriate descriptive terms. Made Ground or Technogenic Sedimentary Ground formed from former anthropogenic formations may be referred as $2^{\text {nd }}$ generation deposits.

Modified from PELOGGIA et al. (2014a, b), PELOGGIA (2015a) and VITORINO et al. (2016).

$(*)$ Categories from BGS artificial ground classification. $(* *)$ Sensu BORJA BARRERA (1993)

TABLE 2 - Facies analysis for technogenic layers (PELOGGIA 2017)

\begin{tabular}{ll}
\hline \multicolumn{1}{c}{ Application rule: the faciological character of the deposit results from the conjunction of the constituent material with the } \\
structure: $(\mathrm{A})+(\mathrm{B})$
\end{tabular}

Modified from VITORINO et al. (2016), based in PELOGGIA (1999) and FANNING \& FANNING (1989). 
The cartographic representation of this classification is illustrated in figure 7 , where the technogenic grounds are identified by class, category and type and, in the case of deposits, the faciological classification is also applied, which is derived from Peloggia's integrated classification proposal, above. The artificial grounds are represented on a map of surficial formations, here generically represented by supposed surficial soils (pedogenic) or colluvium, developed upon granite substrate or Tertiary sediments, and also deposits of quaternary alluvium.

This classification scheme of technogenic ground has been used in practice, with small variations, either in contexts of risk analysis, territorial planning or geoenvironmental analysis, or even in specific maps (thematic) of technogenic ground, carried out with reference to intermediate mapping scales, for example by OLIVEIRA et al. (2015), VITORINO et al. (2016), OLIVEIRA (2017) and PELOGGIA et al. (2018). Figures 8 and 9 show an example of the actual application of the method performed by the latter authors.

As shown by PELOGGIA (2017), the discussed classification includes both those proposed by the British Geological Survey and OLIVEIRA (1990), as well encompasses classifications of anthropogenic "soils" used in Brazil, such as FANNING \& FANNING (1989) and CURCIO et al. (2004), and inserts additional categories (Table 3 ). It should be mentioned that in our opinion (and as argued in detail by PELOGGIA 2017), the term "soil" should be conveniently restricted to the denomination of natural materials from the pedogenesis, to the modification of these materials by human activity or to the resulting layers of pedogenetic processes acting on artificial ground.

Finally, it is important to highlight that the classification of what we are calling geological artificial or technogenic ground has also been the object of intense interest on the part of geoarchaeological studies, as discussed in detail by PELOGGIA (2015a). Table 3 also shows one of the pioneer classifications from this field (BORJA BARRERA 1993), which applies the concept of correlative surficial formation to the study of the humanized natural systems, differentiating occupational anthropic formations, anthropized formations and induced anthropic formations.

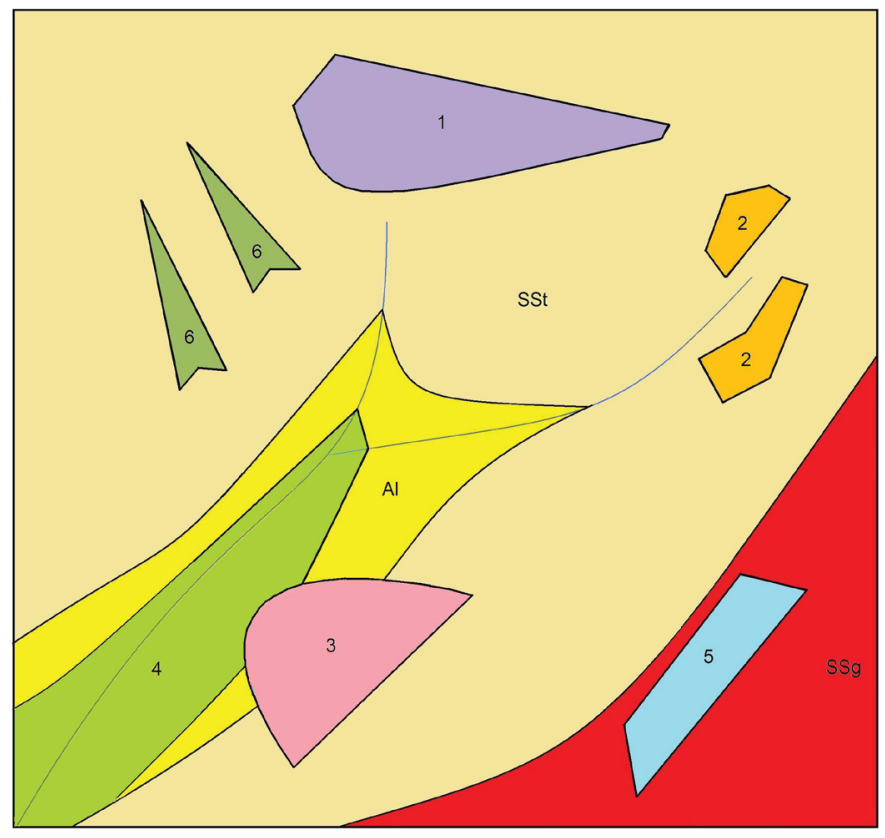
MAP OF TECHNOGENIC
GROUND

AGGRADED GROUND

Made Ground (landfilled)

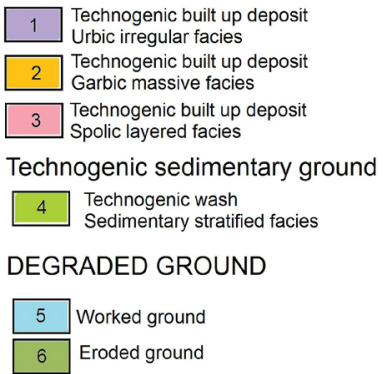

SURFICIAL FORMATIONS

$\mathrm{Al}$ Quaternary alluvium

SSt Surficial soil

SSt upon Tertiaty sediments

Surficial soil

upon granite substratum

FIGURE 7 - Application of the technogenic geodiversity classification to the hypothetical geological situation shown in figure 1. 


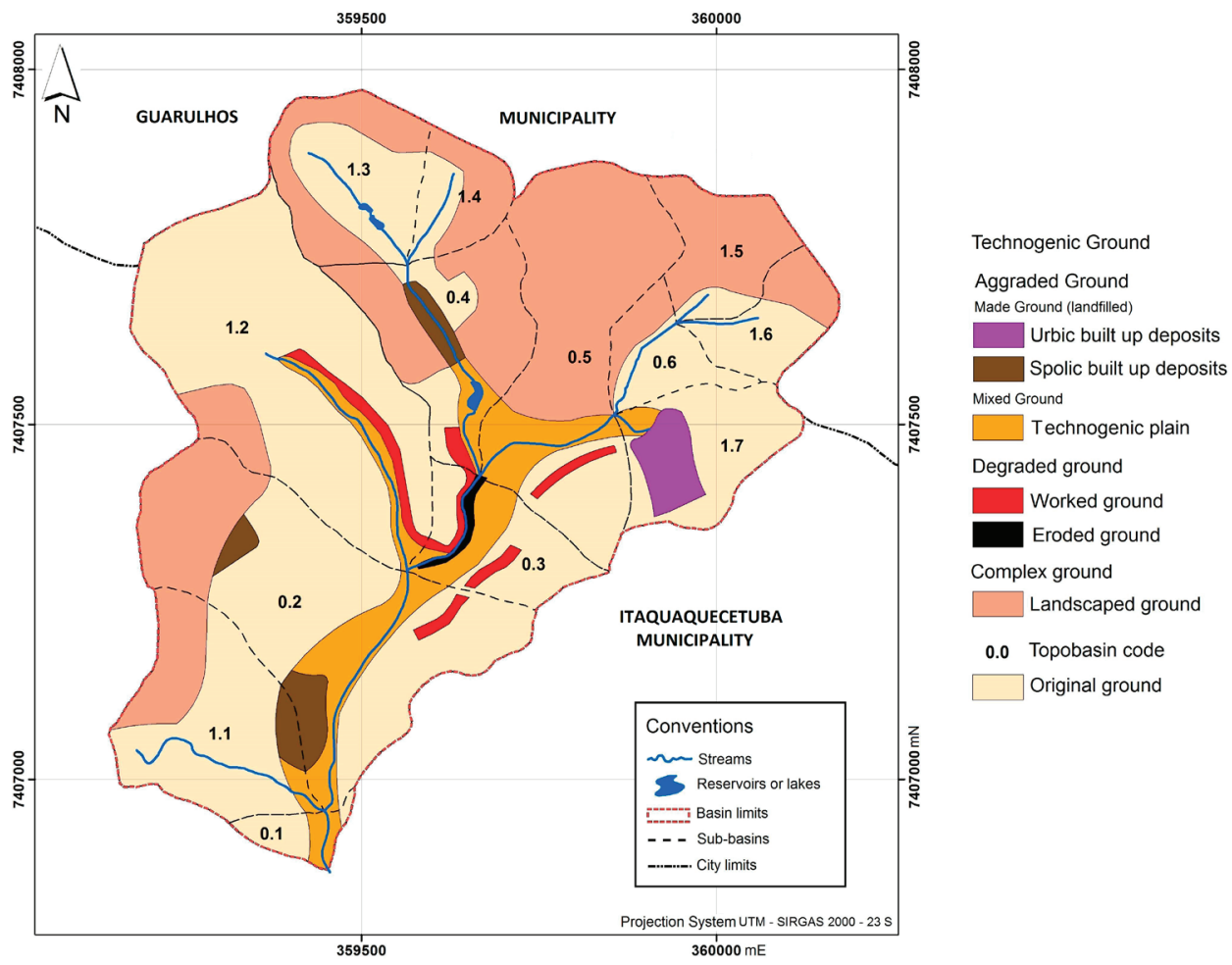

FIGURA 8 - An example of actual technogenic ground map of an urban expansion area in the Água Branca stream basin, Itaquaquecetuba, SP (adapted from PELOGGIA et al. 2018).

TABLE 3 - Correlation between the concepts of anthropogenic ground and "soil", enlarged from PELOGGIA(2017).

\begin{tabular}{|c|c|c|c|c|c|}
\hline \multicolumn{2}{|c|}{$\begin{array}{l}\text { TECHNOGENIC } \\
\text { GROUND } \\
\text { (1) }\end{array}$} & $\begin{array}{l}\text { ARTIFICIAL } \\
\text { GROUND } \\
(2)\end{array}$ & $\begin{array}{l}\text { HIGHLY MAN- } \\
\text { INFLUENCED “SOILS" } \\
\text { (3) }\end{array}$ & $\begin{array}{l}\text { ANTHROPOSOILS } \\
\text { (SUB-ORDERS) } \\
(4)\end{array}$ & $\begin{array}{c}\text { ANTHROPIC } \\
\text { SURFICIAL } \\
\text { FORMATIONS } \\
(5)\end{array}$ \\
\hline \multirow{6}{*}{$\begin{array}{l}\text { Technogenic } \\
\text { Deposits }\end{array}$} & Made Ground & Made Ground & $\begin{array}{l}\text { Urbic } \\
\text { Spolic } \\
\text { Dradged } \\
\text { Garbic } \\
\end{array}$ & $\begin{array}{l}\text { Somic Anthroposoil } \\
\text { Lixic Anthroposoil }\end{array}$ & $\begin{array}{l}\text { Anthropic occupational } \\
\text { formation }\end{array}$ \\
\hline & Infilled Ground & Infilled Ground & & Mobilic Anthroposoil & \\
\hline & $\begin{array}{c}\text { Technogenic } \\
\text { Sedimentary Ground }\end{array}$ & - & - & - & $\begin{array}{c}\text { Induced anthropic } \\
\text { formation }\end{array}$ \\
\hline & Landslided ground & - & - & - & \\
\hline & Displaced ground & - & - & - & Anthopized formation \\
\hline & Mixed ground & $\begin{array}{l}\text { Made } \\
\text { Ground }\end{array}$ & - & - & \\
\hline \multirow{2}{*}{$\begin{array}{l}\text { Technogenic } \\
\text { Soils }\end{array}$} & $\begin{array}{c}\text { Chemically modified } \\
\text { ground }\end{array}$ & - & - & - & Anthopized formation \\
\hline & $\begin{array}{l}\text { Mechanically modified } \\
\text { ground }\end{array}$ & - & - & - & \\
\hline \multirow{4}{*}{$\begin{array}{l}\text { Exposed } \\
\text { substratum }\end{array}$} & Eroded ground & - & - & - & \\
\hline & Scared ground & - & - & - & \\
\hline & $\begin{array}{l}\text { Sunken or disturbed } \\
\text { ground }\end{array}$ & $\begin{array}{l}\text { Disturbed } \\
\text { Ground }\end{array}$ & - & - & \\
\hline & Worked Ground & $\begin{array}{l}\text { Worked } \\
\text { Ground }\end{array}$ & $\begin{array}{l}\text { Scalped land } \\
\text { surfaces }\end{array}$ & $\begin{array}{c}\text { Decapict } \\
\text { Anthroposoil }\end{array}$ & \\
\hline $\begin{array}{l}\text { Technogenic } \\
\text { landscape }\end{array}$ & Landscaped Ground & $\begin{array}{l}\text { Landscaped } \\
\text { Ground }\end{array}$ & 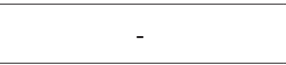 & - & \\
\hline
\end{tabular}

(1) PELOGGIA (2017); (2) MCMILLAN \& POWELL (1999), ROSEMBAUM et al. (2003), PRICE et al. (2004), PRICE et al. (2011); (3)FANNING \& FANNING (1989); (4) CURCIO et al. (2004). Free version in English by A.U.G. Peloggia; (5) BORJA BARRERA (1993) Free version in English by A.U.G. Peloggia. 


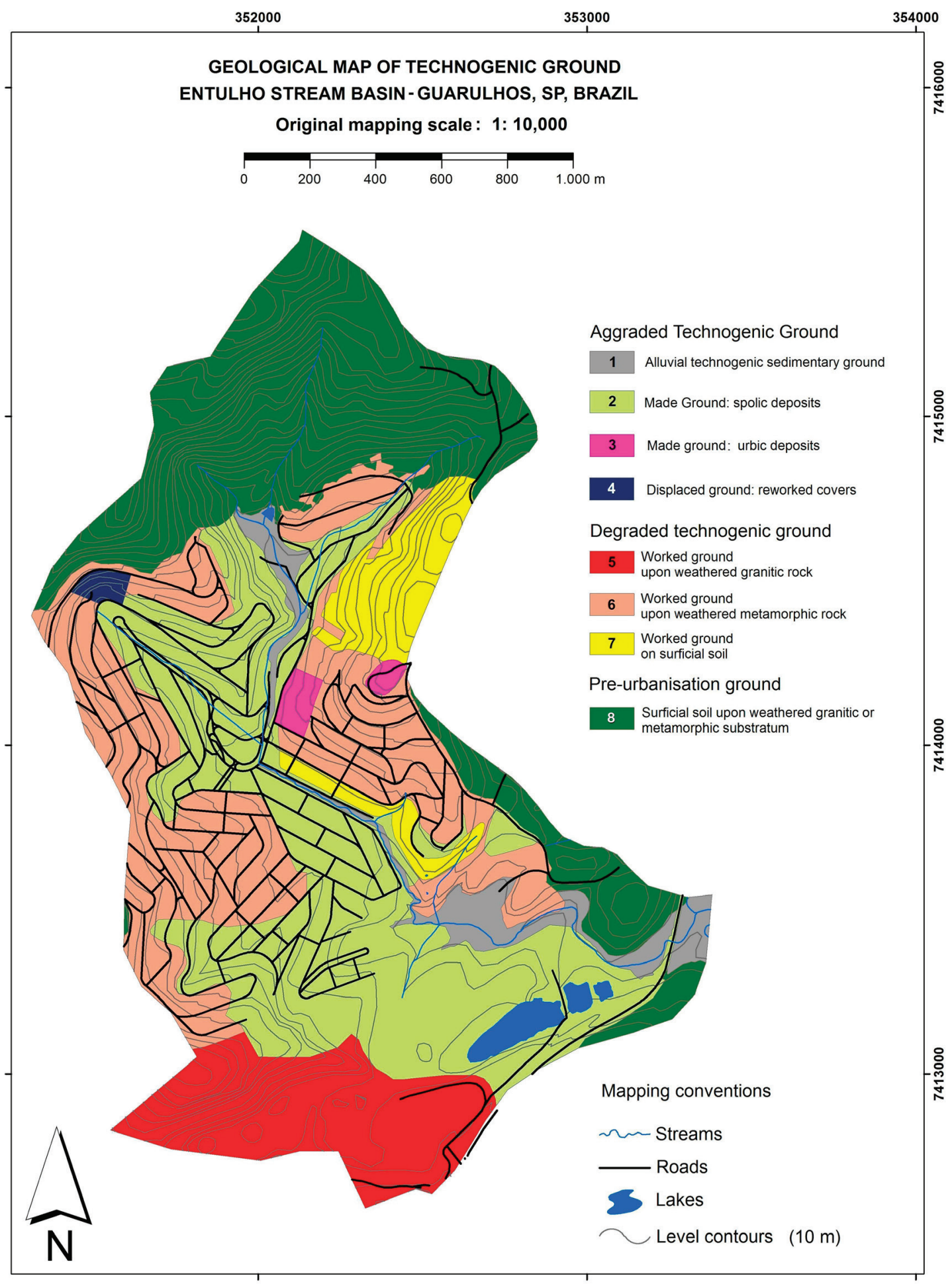

PROJECTION SYSTEM UTM / DATUM SIRGAS 2000

FIGURE 9 - Example of technogenic ground mapping: the Jardim Fortaleza urban area, Guarulhos, SP (adapted from VITORINO et al. 2016). 


\section{FINAL REMARKS}

CHEMEKOV (1983), when presenting the concept of a technogenic deposit as a specific and original geological category, indicated that "in the near future it will be necessary to map the technogenic deposits". This need has, in fact, been reflected in geological and geotechnical mapping as a function of its application to specific situations and demands (for example, hazard analysis), but is also increasingly present in basic geological surveys (such as in the case of the United Kingdom 1: 50,000 mapping), as well as in specific characterization studies of technogenic ground, notably in urban and urban expansion areas or even in the countryside, some of which are cited in this paper.

In this context, due to the specificities of the mapping works, we can conclude the following from what was discussed, in terms of application: 1) for works on super-detailed scales, BARROS \& PELOGGIA (1993) technique seems to be of great applicability; 2) for regional works associated with geological surveys, the British Geological Survey's method of overlapping has been proven; 3) for mappings developed in intermediate or detail scales, the direct cartographic application of the categories of technogenic geodiversity from PELOGGIA (2017) has shown to be of interest and, finally; 4) for all the above hypotheses, the cited proposal of PELOGGIA (2017) can be adapted and applied as the basis of the classification to ground to be mapped, due to its greater conceptual comprehension.

\section{ACKNOWLEDGEMENTS}

The author is grateful to Brian Begley and Thomas Fairchild for their English linguistic support, and to the reviewers of the Revista do Instituto Geológico.

\section{REFERENCES}

BARROS, L.H.; PELOGGIA, A.U.G. 1993. Cartografia geotécnica como fundamento para recuperação de áreas urbanas degradadas: o exemplo da favela Jardim Eliane, município de São Paulo. In: ABGE, CONGRESSO BRASILEIRO DE GEOLOGIA DE ENGENHARIA, 7, Poços de Caldas, Atas, v.2, p. 83-91.
BORJA BARRERA, F. 1993. Formaciones superficiales antrópicas: aportación al estúdio del proceso holoceno de antropización de los sistemas naturales. Arqueologia Espacial, 16-17: 29-39.

BRAGA E.; PElOGgIA, A.U.G.; OliVeIRA, A.M.S. 2016. Análise de risco geológico em encostas tecnogênicas urbanas: o caso do Jardim Fortaleza (Guarulhos, SP, Brasil). Revista UNG-Geociências, 15(1): 27-42.

BROWN, A.; TOMS, P.; CAREY, C.; RHODES, E. 2013. Geomorphology of the Anthropocene: time-transgressive discontinuities of humaninduced alleviation. Anthropocene, 1: 3-13.

CHEMEKOV, Y.F. 1983. Technogenic deposits. In: INQUA, INQUA CONGRESS, 11, Moscow, Abstracts, v.3, p. 62.

CURCIO, G.R.; LIMA, V.C.; GIAROLA, N.F.B. 2004. Antropossolos: proposta de Ordem $\left(1^{\mathrm{a}}\right.$ aproximação). Embrapa Florestas, Colombo, $49 \mathrm{p}$.

DONOVAN, M.; MILLER, A.; BAKER, M.; GELLIS, A. 2015. Sediments contribution from floodplains and legacy sediments to Piedmont streams of Baltimore County, Maryland. Geomorphology, 235: 88-115.

EDGEWORTH, M. 2017. Humanly modified ground. In: D.A. DellaSala \& M.I. Goldstein (ed.) The Encyclopaedia of the Anthropocene. Elsevier, Oxford, v.1, p. 157-161.

FANNING, D.S.; FANNING, M.C.B. 1989. Soil: morphology, genesis and classification. John Wiley \& Sons, New York, 395 p.

FORD, J.; KESSLER, H.; COOPER, A.H.; PRICE, S,J.; HUMPAGE, A.J. 2010. An enhanced classification for artificial ground. British Geological Survey, Nottingham, 29 p.

FORD, J.R.; PRICE, S,J.; COOPER, A.H.; WATERS, C.N. 2014. An assessment of lithostratigraphy of anthropogenic deposits. In: C.N. Waters, J. Zalasiewicz, J.A. Wiliiams, E. Elli \& A.M. Snelling (ed.) A stratigraphical basis for the Anthropocene. Geological Society, London, (Special Publications, 395), p. 55-89. 
FRANÇA Jr., P.; KORB, C.C.; BRANNSTROM, C. 2018. Research on Technogene/ Anthropocene in Brazil. Quaternary and Environmental Geosciences, 9(1): 1-10.

GRIMLEY D.A.; ANDERS, A.M.; BETTIS, E.A.; BATES, B.L.; WANG, J.J.; BUTLER, S.K.; HUOT, S. 2017. Using magnetic fly ash to identify post-settlement alluvium and its record of atmospheric pollution, central USA. Anthropocene, 17: 84-98.

HOWARD J.L. 2014. Proposal to add anthrostratigraphic and technostratigraphic units to the stratigraphic code for classification of anthropogenic Holocene deposits. The Holocene, 24(12): 1856-1861.

HOWARD J. 2017. Anthropogenic soils. Springer International, Cham, $231 \mathrm{p}$.

HUGHES, P.D. 2010. Geomorphology and Quaternary stratigraphy: the roles of morpho-, litho- and allostratigraphy. Geomorphology, 123: 189-199.

JAMES, L.A. 2013. Legacy sediment: definitions and processes of episodically produced anthropogenic sediment. Anthropocene, 2: 16-26.

JAMES, L.A. 2017. Long-term storage and remobilization of legacy sediment: conceptual models of anthropogenic sediment redistribution. GSA, GSA ANNUAL MEETING, Seattle, Abstracts with Programs, 49(6), 1 p.

JORDAN, H.; HAMILTON, K.; LAWLEY, R.; PRICE, S.J.2016. Anthropogenic contribution to the geological and geomorphological record: a case study from Great Yarmouth, Norfolk, UK. Geomorphology, 253: 534546.

LU, Y.; WALDMANN, N.; NADEL, D.; MARCO, S. 2017. Increased sedimentation following the Neolithic Revolution in the Southern Levant. Global and Planetary Change, 152: 199-208.

LYELL, C. 2004 [1863]. The geological evidence of the antiquity of Man. Dover, Mineola (NY), $407 \mathrm{p}$.
MACKLIN, M.G.; LEWIN, J.; JONES, A.F. 2014. Anthropogenic alluvium: an evidencebased meta-analysis for the UK Holocene. Anthropocene, 6: 26-38.

McMILLANA.A.; POWELL J.H. 1999. BGS Rock Classification Scheme: V4 - Classification of artificial (man-made) ground and natural superficial deposits. British Geological Survey, Nottingham, 65 p. (BGS Research Report n. RR 99-04).

MEIS, M.R.M.; MOURA, J.R.S. 1984. Upper Quaternary sedimentation and hillslope evolution: Southeastern Brazilian Plateau. American Journal of Sciences, 284: 241254.

MIRANDOLA, F.A.; MACEDO, E.S. 2014. Proposta de classificação do Tecnógeno para uso no mapeamento de áreas de risco de deslizamentos. Quaternary and Environmental Geosciences, 5(1): 66-81.

MOURA, J.R.S. 1994. Geomorfologia do Quaternário. In: A.J.T. GUERRA; S.B. CUNHA (orgs.) Geomorfologia: uma atualização de bases e conceitos. Bertrand Brasil, Rio de Janeiro, c. 8, p. 335-364.

NIREI, H.; FURUNO, K.; OSAMU, K.; MARKER, B.; SATKUNAS, J. 2012. Classification of man-made strata for assessment of geopollution. Episodes, 35(2): 333-336.

NOLASCO, M. 1998. Depósitos antrópicos tecnogênicos: um conceito em discussão na Geologia. Instituto de Geociências, Universidade Federal do Rio Grande do Sul, Porto Alegre, Monografia de Qualificação, $63 \mathrm{p}$.

OLIVEIRA, A.M.S. 1990. Depósitos tecnogênicos associados à erosão atual. In: ABGEABMS, CONGRESSO BRASILEIRO DE GEOLOGIA DE ENGENHARIA, 6, Salvador, Anais, v.1, p. 411-415.

OLIVEIRA, A.M.S.; BRANNSTROM, C.; NOLASCO, M.C.; PELOGGIA, A.U.G.; PEIXOTO, M.N.; COLTRINARI, L. 2005. Tecnógeno: registros geológicos da ação humana. In: C.R.G. Souza, K. Suguio, A.M.S. Oliveira \& P.E. Oliveira. (eds.) 
Quaternário do Brasil. Holos, Ribeirão Preto, c. 17, p. 363-378.

OLIVEIRA, S.A.; PEIXOTO, M.N.O.; MELLO, E.V. 2015. Lugares de perigo na Cidade do Aço: uma discussão sobre geotecnogênese, vulnerabilidade e risco ambiental em Volta Redonda (RJ). In: ANPEGE, ENCONTRO NACIONAL DA ANPEGE, 9, Presidente Prudente, Anais, p. 6471-6481.

OLIVEIRA, S.A. 2017. Vulnerabilidade ambiental na "Cidade do Aço": a geotecnogênese na construção de paisagens de perigo no Setor Leste de Volta Redonda (RJ). Programa de Pós-Graduação em Geografia, Universidade Federal do Rio de Janeiro, Rio de Janeiro, Dissertação de Mestrado, 215 f.

PELOGGIA, A.U.G. 1994. As coberturas remobilizadas: depósitos tecnogênicos de encostas urbanas no município de São Paulo. Solos e Rochas, 17(2): 120-125.

PELOGGIA A.U.G. 1997. A classificação dos depósitos tecnogênicos urbanos. In: SBG, SIMPÓSIO DE GEOLOGIA DO SUDESTE, 5, Penedo (Itatiaia, RJ), Atas, p.181-183.

PELOGGIA, A.U.G. 1998. O homem e o ambiente geológico: geologia, sociedade e ocupação urbana no município de São Paulo. Xamã, São Paulo, 231 p.

PELOGGIA, A.U.G. 1999. Sobre a classificação, enquadramento estratigráfico e cartografação dos depósitos tecnogênicos. In: Prefeitura do Município de São Paulo /SEHAB /HABI, Estudos de Geotécnica e Geologia Urbana (I), São Paulo (Manual Técnico 3 - GTGEOTEC), p. 35-50.

PELOGGIA, A.U.G. 2015a. Camadas que falam sobre o ser humano, caso encontrem arqueólogos e geólogos que as escutem: rumo a uma arqueogeologia interpretativa dos depósitos tecnogênicos. In: A.M. Ortega \& A.U.G. Peloggia (org.), Entre o Arcaico e o Contemporâneo: ensaios fluindo entre Arqueologia, Psicanálise, Antropologia e Geologia. Iglu, São Paulo, p. 189-221.

PELOGGIA, A.U.G. 2015b. O significado arqueológico dos depósitos tecnogênicoaluviais da bacia do rio Una (Taubaté, SP).
Revista de Arqueologia Pública, 9-3(13): 207-219.

PELOGGIA, A.U.G. 2016. Relíquias da destruição: registros arqueogeológicos da supressão da Mata Atlântica no Vale do Paraíba. In: D.C. Cabral \& A.G. Bustamante (orgs.) Metamorfoses Florestais: culturas, ecologias e as transformações históricas da Mata Atlântica. Prismas, Curitiba, p. 286-304.

PELOGGIA, A.U.G. 2017. O que produzimos sob nossos pés? Uma revisão comparativa dos conceitos fundamentais referentes a solos e terrenos antropogênicos. Revista UNG Geociências, 16(1): 102-127.

PELOGGIA, A.U.G.; SILVA E.C.N.; NUNES J.O.R. 2014a. Technogenic landforms: conceptual framework and application to geomorphologic mapping of artificial ground and landscape as transformed by human geological action. Quaternary and Environmental Geosciences, 5(2): 67-81.

PELOGGIA, A.U.G.; OLIVEIRA A.M.S.; OLIVEIRA A.A.; SILVA E.C.N.; NUNES J.O.R. 2014b. Technogenic geodiversity: a proposal on the classification on artificial ground. Quaternary and Environmental Geosciences, 5(1): 28-40.

PELOGGIA, A.U.G.; CAPELLARI, B.; SHIKAKO, A.S. 2015. Registros geológicos tecnogênico-sedimentares (antropocênicos) no Vale do Paraíba do Sul (Taubaté, SP): a aloformação Rio Una. In: SBG-SP, SIMPÓSIO DE GEOLOGIA DO SUDESTE, 14, Campos do Jordão, Anais, 5 p.

PELOGGIA, A.U.G.; SAAD, A.R.; SILVA, R.V.; QUEIROZ, W. 2018. Processos de formação de terrenos e relevos tecnogênicos correlativos à urbanização: análise morfoestratigráfica e geoambiental aplicada na bacia do córrego Água Branca, Itaquaquecetuba (RMSP). Revista Brasileira de Geomorfologia, 19(2): 245-265.

PRICE S.J.; FORD J.R.; KESSLER H.; COOPER A.; HUMPAGE A. 2004. Artificial ground: mapping our impact on the surface of the Earth. Earthwise, 20: 30-32. 
PRICE S.J., FORD J.R., COOPER A.H., NEAL C. 2011. Human as major geological and geomorphological agents in the Anthropocene: the significance of artificial ground in Great Britain. Philosophical Transactions of the Royal Society. 369: 10561086.

PROCTER, P. 1995. Cambridge International Dictionary of English. Cambridge University Press, Cambridge, 1774 p.

RICHARDSON, J.M.; FULLER, I.C.; HOLT, K.A.; LITCHFIELD, N.J.; MACKLIN, M.G. 2014. Rapid post-settlement floodplain accumulation in Northland, New Zealand. Catena, 113: 292-305.

\section{ROSEMBAUMM.S.;McMILLANA.A.;POWELL} J.H.; COOPER A.H.; CULSHAW M.G.; NORTHMORE K.J. 2003. Classification of artificial (man-made) ground. Engineering Geology, 69(3-4): 399-409.

ROYALL, D.; KENNEDY, L. 2016. Historic erosion and sedimentation in two small watersheds od the Southern Blue Ridge Mountains, North Carolina, USA. Catena, 143: 174-186.

SANTOS, E.Q.D.; FERREIRA, A.T.S.; PELOGGIA, A.U.G.; SAAD, A.R.; OLIVEIRA, A.M.S.; SANTOS. M.S.T. 2017. Terrenos e processos tecnogênicos na área de proteção ambiental Cabuçu-Tanque Grande, Guarulhos (SP): análise, mapeamento e quantificação. Revista Brasileira de Geomorfologia, 18(4): 825-839.

SHERLOCK, R.L. 1922. Man as a geological agent: an account of his action on inanimate nature. H.F. \& G. Witherby, London, 372p.
SUESS, E. 1862. Der boden der stadt Wien. Wilhelm Braumüller, Wien, 326p.

TER STEPANIAN, G. 1988. Beginning of the Technogene. Bulletin IAEG, 38: 133-142.

TRIMBLE, S.W. 2008. Classics in physical geography revisited: Happ, S.C., Rittenhouse, G. and Dobson, G.C. 1949: some principles of accelerated stream and valley sedimentation. US Department of Agriculture Technical Bulletin 695. Progress in Physical Geography, 32(3): 337-345.

VITORINO, J.C.; ANDRADE, M.R.M.; PELOGGIA, A.U.G.; SAAD, A.R.; OLIVEIRA, A.M.S. 2016. Terrenos tecnogênicos do Jardim Fortaleza, bacia hidrográfica do córrego do Entulho, Guarulhos (SP): mapeamento geológico, estratigrafia, geomorfologia e arqueologia da paisagem. Revista UNG - Geociências, 15(2): 33-60.

WATERS, C.N. 2018. Artificial ground. In: P.T. Bobrowsky, B. Marker, B. (eds.) Encyclopaedia of Engineering Geology. Springer International, Cham, p. 1-15.

ZALASIEWICZ, J.; WILLIAMS, M.; WATERS, C.N.; BARNOVSKY, A.D.; HAFF, P. 2014. The technofossil record. The Anthropocene Review, 1(1): 34-43.

ZALASIEWICZ, J.; WATERS, C.N.; IVAR DO SUL, J.A.; CORCORAN, P.L.; BARNOSKY, A.D.; CEARRETA, A.; EDGEWORTH, M.; GAHISKA, A.; JEANDEL, C.; LEINFELDER, R.; MCNEILL， J.R.; STEFFEN, W.; SUMMEERHAYES, C.; WAGREICH, M.; WILLIAMS, M.; WOLFE, A.P.; YONAN, Y. 2016. The geological cycle of plastics and their use as a stratigraphic indicator of the Anthropocene. Anthropocene, 13: 4-17.

Author's address:

Alex Ubiratan Goossens Peloggia - Av. São Luís 71, ap. 304, CEP: 01046-001, São Paulo, SP, Brasil. E-mail: alexpeloggia@uol.com.br.

Manuscript submitted in 27 June 2018, accepted in 28 August 2018. 